\title{
PARADIGMA SOSIAL PROFETIK DALAM KODE ETIK POLITIK DI INDONESIA
}

\author{
Athoillah Islamy \\ Institut Agama Islam Negeri Pekalongan \\ Athoillahislamy@yahoo.co.id
}

\begin{abstract}
:
This study aims to reveal social prophetic values in the principles of political ethics in Indonesia. This research is a qualitative research in the form of literature review. This type of legal research is normative legal research with a philosophical approach. The primary data source of this research is the text of the code of ethics of politicians and political parties. Meanwhile, secondary data sources use various scientific studies that are relevant to the object of discussion. The analytical theory approach used is Kuntowijoyo's social prophetic paradigm theory. This study concludes that the various principles of political ethics in Indonesia are parallel with the values of humanization, liberation and transcendence. First, the principle of public benefit is parallel to the teachings of ukhuwah insaniyah and ta'awun insani. Second, the principle of honesty is parallel to the nature of shiddiq. Third, the principles of integrity and professionalism are parallel to the teachings of the khaira ummah, justice, deliberation, ulul albab, Imamat, and tauhid which are liberating. Fourth, the principle of accountability parallel with amanah. Fifth, this principle of justice is parallel to the universal teaching of Islam in the form of al-adalah.
\end{abstract}

Keywords: Social, prophetic, code of ethics, politics, Indonesia

\begin{abstract}
Abstrak:
Penelitian ini bertujuan untuk mengungkap nilai-nilai sosial profetik dalam prinsip kode etik politik di Indonesia. Penelitian ini merupakan penelitian kualitatif yang berupa kajian pustaka. Jenis penelitian hukum ini adalah penelitian hukum normatif dengan pendekatan filosofis. Sumber data primer penelitian ini yakni naskah kode etik politisi dan partai politik. Sedangkan sumber data sekunder menggunakan berbagai penelitian ilmiah yang relevan dengan objek pembahasan. Pendekatan teori analisis yang digunakan adalah teori
\end{abstract}


paradigma sosial profetik Kuntowijoyo. Penelitian ini menyimpulkan pelbagai prinsip kode etik politik di Indonesia paralel dengan nilai humanisasi, liberasi dan transendensi. Pertama, prinsip kemaslahatan publik paralel dengan ajaran ukhuwah insaniyah dan ta'awun insani. Kedua, prinsip kejujuran paralel dengan sifat shiddiq. Ketiga, prinsip integritas dan profesionalisme paralel dengan ajaran khaira ummah, keadilan, musyawarah, ulul albab, imamah, dan tauhid yang membebaskan. Keempat, prinsip akuntabilitas. paralel dengan sifat amanah. Kelima, prinsip keadilan ini paralel dengan ajaran universal Islam yang berupa al-adalah.

Kata Kunci : Sosial, profetik, kode etik, politik, Indonesia

\section{A. PENDAHULUAN}

Peran strategis sebuah partai politik tidak dapat dilepaskan dari berbagai fungsi yang melekat pada partai politik itu sendiri, seperti rekrutmen politik, komunikasi politik, artikulasi dan agregasi kepentingan, pendidikan politik, sosialisasi politik, pengendalian konflik, perwakilan politik, identifikasi politik dan lain sebagainya. ${ }^{1}$ Namun demikian dalam menjalankan ragam fungsi partai politik tersebut tidak jarang terjadi deviasi kekuasaan oleh mereka yang terlibat sebagai aktor politik (politisi). ${ }^{2}$ Hal demikian dapat dilihat dari pelbagai kasus korupsi, kolusi, dan Nepotisme (KKN) sebagaimana yang terjadi pada pelbagai daerah di Indonesia. ${ }^{3}$

Sebagaimana contoh kasus korupsi yang telah menjadi patologi sosial sebagai tindakan yang merusak struktur dan tatanan pemerintahan. ${ }^{4}$

${ }^{1}$ Syamsuddin Haris dkk, Naskah Kode Etik Politisi dan Partai Politik (Jakarta : P2Politik LIPI, 2016), 2.

${ }^{2}$ Syamsuddin Haris dkk, Naskah Kode Etik Politisi dan Partai Politik, 2.

${ }^{3}$ Ismansyah, Purwantoro Agung Sulistyo, "Permasalahan Korupsi, Kolusi, dan Nepotisme di Daerah serta Strategi Penanggulangannya," Demokrasi, Vol. IX No. 1 (2010):43

${ }^{4}$ Salah satu dampak negatif dari pembangunan adalah tindak pidana korupsi. Indonesia merupakan salah satu negara dengan tingkat korupsi yang tinggi. Hampir semua kabupaten memiliki kasus korupsi dan sebagian besar departemen di negeri ini memiliki indikasi untuk korup. Dengan kata lain, korupsi di Indonesia adalah penyakit 
Tidak dapat dipungkiri jika tindakan korupsi berpotensi besar dalam menghambat jalannya roda pemerintahan dan pembangunan negara. ${ }^{5} \mathrm{Hal}$ demikian disebabkan keberadaan negara yang dalam struktur pemerintahannya dikomandoi pejabat yang koruptor, maka akan mengalami keterpurukan ekonomi, yang dampaknya tidak hanya pada pelbagai program pembangunan pemerintah, melainkan juga pada kehidupan ekonomi masyarakat secara luas. ${ }^{6}$

Problem prilaku politik di atas yang kemudian menimbulkan pemeo di masyarakat, bahwa jika partainya baik, maka demokrasi yang dihadirkannhya akan baik. Namun sebaliknya, jika partainya buruk, akan berdampak buruk dalam pelbagai sistem di sebuah negara, tidak hanya pada sistem demokrasi, melainkan juga sistem ekonomi, hukum ${ }^{7}$ dan pelbagai sistem lainnya. pelbagai fenomena problem prilaku politik yang ada meniscayakan pentingnya seperangkat norma yang mengatur kode

menular. Jika kondisi seperti itu masih terus terjadi, maka akan menghambat pembangunan dan mengancam integrasi negara ini, karena korupsi memiliki implikasi untuk semua sektor dalam kehidupan negara. Ida Bagus Ketut Weda, "Korupsi Dalam Patologi Sosial : Sebab, Akibat Dan Penanganannya Untuk Pembangunan Di Indonesia," Jurnal Advokasi, Vol.3, No.2 (2013):119.

${ }^{5}$ Kategori korupsi dalam birokrasi pemerintahan dapat dikategorikan menjadi tiga jenis. Pertama, grand corruption, yakni sumber daya publik dicuri atau disalahgunakan oleh pejabat publik. Kedua, state or regulatory capture, yakni lembaga publik dengan swasta bekerja sama untuk memperoleh keuntungan pribadi melalui tindakan kolusi. Ketiga, bureaucratic or petty corruption, yakni pejabat publik menyalahgunakan kekuasaan untuk memperoleh sogokan kecil. Irfan Setiawan, "Mengikis Perilaku Korupsi Pada Birokrasi Pemerintahan," Jurnal Ilmu Pemerintahan Widyapraja IPDN Vol XLII No. 1 (2016) : 33-34

6 Latipah, "Korupsi di Parlemen," 'Adalah : Buletin Hukum dan Keadilan, Vol.1,No.1 (2017) :3.

${ }^{7}$ Dinamika politik dapat mempengaruhi perkembangan dan karakter produk hukum di suatu negara. Keberadaan kondisi politik yang demokratis akan dapat melahirkan produk hukum yang responsif terhadap kebutuhan rakyat. Sebalinya, kondisi politik yang otoriter akan melahirkan produk hukum yang ortodok. Athoillah Islamy, "Eksistensi Hukum Keluarga Islam di Indonesia dalam Kontestasi Politik Hukum dan Liberalisme Pemikiran Islam," Al-Istinbath : Jurnal Hukum Islam, Vol.4, No.2 (2019) :166-167. 
etik prilaku politik, ${ }^{8}$ baik bagi politisi maupun partai politik agar dapat menjalankan fungsi dan perannya secara ideal.

Dalam konteks Indonesia, tepatnya pada tahun 2016 sejatinya telah lahir buku naskah kode etik politisi dan partai politik yang diterbitkan oleh Direktorat Pendidikan dan Pelayanan Masyarakat Kedeputian Pencegahan, Komisi Pemberantasan Korupsi Bekerja sama dengan Pusat Penelitian Politik, Lembaga Ilmu Pengetahuan Indonesia. Buku Naskah Kode Etik Partai Politik dan Politisi ini dibuat agar menjadi pedoman bagi politis dan partai politik dalam menjalankan peran dan fungsi politisi dan partai politik, khususnya di Indonesia. ${ }^{9}$

Meski sudah terdapat naskah kode etik politisi dan partai politik, fakta di lapangan menunjukan bahwa penanganan kasus kerugian keuangan negara yang dilakukan oleh para politisi masih menjadi fakta empiris yang masih saja ditemukan di Indonesia. Hal ini dapat dilihat sejak keberadaan Komisi Pemberantasan Korupsi $(\mathrm{KPK})^{10}$ dibentuk hingga tahun 2019, ditemukan kurang lebih sekitar 107 Kepala Deerah yang teridentifikasi kasus korupsi. Tidak hanya itu, selama periode 2014-2019 setidaknya terdapat 23 anggota DPR RI aktif yang juga terjerat kasus

${ }^{8}$ Perhatian utama memahami perilaku politik terletak pada hubungan antara pengetahuan politik dan tindakan politik. Seseorang yang melakukan suatu tindakan pasti dimotivasi oleh satu atau beberapa faktor yang mendorong tindakan tersebut, dari faktor-faktor yang mendasari tindakan tersebut, akan ada suatu ikatan sebab akibat mengapa tindakan atau perilaku politik dia lakukan. Abdul Basit Atamimi, Athoillah Islamy, "Political Thinking And Attitude Of Religion:Study Of Political Resistance Of Kiai Ahmad Rifa 'I Kalisalak Al-Jawi On Colonialism Of The Netherlands," Akademika: Jurnal Keagamaan dan Pendidikan, Vol. 15 No. 2 (2019):128.

${ }^{9}$ Syamsuddin Haris dkk, Naskah Kode Etik Politisi dan Partai Politik, V.

10 Komisi Pemberantasan Korupsi (KPK) di Indonesia memiliki kewenangan tugas, sebagai berikut. Pertama, Koordinasi dengan instansi yang berwenang dalam melakukan pemberantasan tindakan korupsi. Kedua, supervise terhadap lembaga yang memiliki wewenang untuk memberantas tindakan korupsi. Ketiga, penyelidik, penyidik, dan penuntut atas tindakan korupsi. Keempat, mewujudkan pelbagai tindakan dalam upaya pencegahan korupsi. Kelima, memonitoring penyelenggaraan pemerintahan negara. I Wayan Yuda Satria, I Wayan Suardana, Ida Bagus Surya Darmajaya "Kewenangan Komisi Pemberantasan Korupsi (Kpk) Dalam Upaya Pemberantasan Tindak Pidana Korupsi Di Indonesia," Ketha Semaya, Vol.1, No.1 (2013) :3. 
korupsi melalui tangkap tangan. ${ }^{11}$ Dengan demikian dapat dipahami bahwa keberadaan naskah kode etik politisi dan partai politik masih belum dapat dikatakan efektif. Oleh sebab itu dibutuhkan strategi lain dalam menguatkan eksistensi naskah tersebut, seperti halnya nilai-nilai profetik ajaran agama. ${ }^{12}$

Berpijak pada kegelisahan akademik penulis yang telah diuraikan pada latar belakang di atas, penelitian ini bertujuan untuk mengungkap nilainilai profetik sosial ajaran Islam dalam pelbagai prinsip kode etik politik yang terdapat dalam naskah kode etik politisi dan partai politik. Hal demikian penting dilakukan untuk menyadarkan kembali bahwa berbagai prinsip kode etik politik dalam naskah tersebut sejatinya memiliki relevansi, bahkan paralel dengan nilai-nilai profetik sosial dalam ajaran Islam, sehingga diharapkan dapat menyadarkan kembali para politisi maupun institusi partai politik atas pentingnya menjadikan prinsip kote etik politik yang termaktub dalam naskah kode etik politisi dan partai politik sebagai acuan dalam menjalankan tugas politisi dan partai politik di tengah kehidupan bermasyarakat dan bernegara, terlebih bagi para politisi yang beragama Islam maupun partai politik Islam. ${ }^{13}$

11 Donal Fariz, "Pemerintahan Joko Widodo dan Serangan Politik Terhadap KPK," Jurnal Antikorupsi Integritas, Vol. 5 No.2 (2019) : 23.

12 Kasinyo Harto, "Pendidikan Anti Korupsi Berbasis Agama," Intizar, Vol. 20, No. 1, (2014): 134. Implementasi pendidikan spritual menekankan pembentukan karakter individu peserta didik agar memiliki potensi kecerdasan seimbang pada pelbagai potensi dirinya, meliputi potensi kecerdasan emosi, rohani dan intelektual yang mengacu pada ajaran agama. Nurul Istiani, Athoillah Islamy,"Objektifikasi Nilai-nilai Psiko Sufistik dalam Pendidikan Spritual," Hikmatuna : Journal Integrative For Islamic Studies, Vol. 4, No. 2 (2018) : 241.

13 Sebagian partai Islam di Indonesia dipandang telah bergeser pada skema tindakan pragmatis, meninggalkan tindakan ideologis dalam dasar kebijakan politiknya. Oleh sebab itu, sebagian partai Islam di tengah masyarakat dinilai tidak lagi memiliki identitas dan platform yang jelas, sehingga tidak jauh berbeda dengan partai-partai nasionalis sekuler pada umumnya. Ari Ganjar Herdiansah, "Pragmatisme Partai Islam Di Indonesia: Pendekatan Tindakan Sosial," Sosioglobal : Jurnal Pemikiran Politik, Vol.1, No.2 (2017) : 152 


\section{B. LITERATURE REVIEW}

Terdapat beberapa penelitian terdahulu yang relevan dengan pembahasan penelitian ini, antara lain sebagai berikut.

Nur Rohim Yunus (2014) dalam penelitiannya menyimpulkan perilaku etis-moral merupakan hal yang urgen dan tidak dapat ditawar lagi bagi kehidupan politik para anggota dewan. Hal demikian tidak lain, agar para anggota dewan dapat menjadikan etika dan moralitas sebagai pijakan dasar sekaligus orientasi berpolitik. Melalui etika dan moralitas yang baik tersebut dapat mengantarkan mereka menjadi politikus sejati pengemban tugas mulia. ${ }^{14}$

Paralel dengan Nur Rohim Yunus, Nur Habibi (2014) dalam penelitiannya juga menyatakan bahwa keberadaan pengadilan etika internal DPR RI memiliki manfaat yang positif dalam menjaga kewibawaan dan harkat martabat para politisi di parlemen agar dapat menalankan mandatnya sesuai Undang-Undang Dasar NRI 1945, Undang- Undang Nomor 27 Tahun 2009 Tentang MPR, DPR, DPD dan DPRD, serta undang-undang lainnya. ${ }^{15}$

Selanjutnya, Mustika Purbaningrum Kusumawati (2019) dalam penelitiannya menyimpulkan bahwa ketika pejabat publik tidak dapat memisahkan dan membedakan wilayah publik dan privat (pribadi) dalam posisinya sebagai pejabat publik dan sekaligus politik, maka dapat berdampak negatif terhadap pelayanan publik yang diberikan ke masyarakat. Tindakan yang tidak tepat tersebut sejatinya tidak sekedar disebabkan oleh pejabat publik yang tidak menghayati arti dan pentingnya etika publik, melainkan juga karena disebabkan tidak mengert

${ }^{14}$ Nur Rohim Yunus, “Etika dan Moralitas Politik Anggota Dewan,” Mizan: Jurnal Ilmu Syariah. Vol.2, No. 2 (2014).

${ }^{15}$ Nur Habibi, "Praktik Pengawasan Etika Dewan Perwakilan Rakyat Republik Indonesia," Jurnal Cita Hukum, Vol.1, No.1 (2014). 
apa itu etika publik. ${ }^{16}$

M. Nasir Djamil dan TB. Massa Djafar (2016) dalam penelitiannya berupaya memaparkan dampak dari tindakan korupsi di mata publik. Menurut Djamil dan Djafar, pelanggaran etika pejabat negara berupa tindakan yang tidak jujur, memanipulasi data dan tidak transparan. Pelanggaran politik tersebut berimplikasi pada melemahnya kepercayaan publik terhadap kondisi pemerintahan yang bersih, terlebih pada keberadaan para pejabat partai politik. ${ }^{17}$

Berikutnya, Dwi Yanto (2017) dalam penelitiannya menjelaskan bahwa Pancasila sebagai dasar dan pedoman kehidupan dalam bernegara di Indonesia, sebagai pedoman harus dipahami, dihayati dan dimanifestasikan dalam kehidupan berpolitik.Oleh sebab itu, proses pengambilan keputusan dan kebijakan politik harus memuat pelbagai nilai Pancasila sebagai nilai etika politik di Indonesia. ${ }^{18}$

Anang Setiawan dan Erinda Alfiani Fauzi (2019) dalam penelitiannya berupaya untuk menguraikan faktor penyebab terjadinya korupsi. Menurut Anang dan Erinda, fenomena korupsi yang terjadi berbagai wilayah di terjadi di Indonesia yang berkaitan dengan etika kepemimpinan politik. Perilaku korupsi memang dipengaruhi oleh banyak hal, namun pada penelitian ini fokus membahas tentang dimana etika dan moralitas yang mempengaruhi perilaku korupsi yang dilakukan oleh pemimpin di Indonesia. ${ }^{19}$

Berdasarkan hasil penelusuran penulis, belum ditemukan penelitian

${ }^{16}$ Mustika Purbaningrum Kusumawati, "Harmonisasi Antara Etika Publik Dan Kebijakan Publik," Jurnal Yuridis, Vol. 6 No. 1 (2019)

17 M. Nasir Djamil dan TB. Massa Djafar, "Etika Publik Pejabat Negara dalam Penyelenggaraan Pemerintahan yang Bersih,"Jurnal Politik, Vol.12, No.1 (2016).

18 Dwi Yanto, "Etika Politik Pancasila," Ittihad Jurnal Kopertais Wilayah XI Kalimantan Vol.15, No.27(2017)

19 Anang Setiawan, Erinda Alfiani Fauzi, "Etika Kepemimpinan Politik Dalam Penyelenggaraan Pemerintahan Indonesia," Jurnal Pemerintahan dan Kebijakan, Vol.1, No.1 (2019). 
terdahulu yang fokus mengkaji eksplorasi nilai-nilai sosial profetik dari pelbagai prinsip politik yang termaktub dalam naskah kode etik politisi dan partai politik. Hal inilah yang mungkin distingsi penelitian ini dari penelitain lain, sekaligus mengisi ruang kosong (lacuna) peneltian yang sudah ada.

\section{METODE PENELITIAN}

Penelitian ini termasuk dalam kategori penelitian kualitatif yang berupa kajian pustaka (library research) ${ }^{20}$ Jenis penelitian hukum dalam penelitian ini masuk kategori penelitian hukum normatif. ${ }^{21}$ Objek utama penelitian ini, yakni pelbagai prinsip kode etik politik yang terdapat dalam naskah kode etik politisi dan partai politik yang diterbitkan oleh Direktorat Pendidikan dan Pelayanan Masyarakat Kedeputian Pencegahan, Komisi Pemberantasan Korupsi Bekerja sama dengan Pusat Penelitian Politik, Lembaga Ilmu Pengetahuan Indonesia (LIPI). Jenis pendekatan yang digunakan yakni pendekatan filosofis. Sementara itu, teori analisis yang digunakan yakni teori ilmu sosial profetik yang digagas Kuntowijoyo.

\section{TIGA PILAR PARADIGMA SOSIAL PROFETIK}

Di tengah arus perdebatan antara pelbagai ilmu sosial Barat sekuler

${ }^{20}$ Penelitian kualitatif merupakan penelitian yang bertujuan untuk menganalisa objek penelitian secara holistik, deskriptif tanpa metode analisis statistik. Lexy J. Moleong, Metodologi Penelitian Kualitatif (Bandung : Remaja Rosdakarya, 2017), 6. Adapun contoh penelitian pustaka (library research), antara lain penelitian terhadap kitab suci, buku ilmiah, peraturan perundang undangan, dan lain sebagainya. Baca Panduan Karya Tulis Ilmiah Pascasarjana UIN Walisongo (Semarang : Pascasarjana UIN Walisongo, 2018), 35.

${ }^{21}$ Penelitian hukum normatif juga dapat disebut sebagai penelitian hukum doktriner, penelitian perpustakaan, maupun studi dokumenter. Hal demikian disebabkan penelitian hukum normatif dilakukan pada objek penelitian hukum yang berupa peraturan-peraturan yang tertulis. Ishaq, Metode Penelitian Hukum dan Penulisan Skripsi, Tesis serta Disertasi (Bandung : Alfabeta, 2017), 27. 
dan ilmu sosial Islam, Kuntowijoyo ${ }^{22}$ menawarkan gagasan yang orisinal dan kritis dalam ilmu sosial yang disebutnya dengan Ilmu Sosial Profetik (ISP). Melalui ISP tersebut, Kuntowijoyo berupaya membangun jalan yang menjembatani antara ilmu sosial sekuler dan kecenderungan untuk melakukan Islamisasi ilmu sosial. ${ }^{23}$

Ide tentang Ilmu Sosial Profetik (ISP) yang digagas oleh Kuntowijoyo menekankan pentingnya ilmu sosial memiliki pijakan nilai dalam tujuan yang akan dicapainya. Oleh sebab itu, gagasan ISP tidak sekedar berhenti pada upaya untuk menjelaskan dan memahami realitas secara apa adanya, melainkan juga penting mentransformasikan pelbagai cita luhur yang didambakan dalam kehidupan sosial. Atas dasar ini, Ilmu Sosial Profetik yang digagas oleh Kuntowijoyo merumuskan tiga nilai dasar yang menjadi pijakan dan sekaligus unsur pembentuk karakter paradigmatiknya, yakni humanisasi (amar makruf), liberasi (nahi munkar) dan transendensi (keimanan) yang diderivasikan dari misi historis Islam sebagaimana termuat dalam Qs. Ali Imran, ayat 110.24 Ketiga nilai dasar profetik Islam tersebut bukan hal yang bersifat dikotomis melainkan

${ }^{22}$ Selain sebagai salah satu cendikiawan muslim di Indonesia, Kuntowijoyo juga dikenal sebagai sastrawan, sejarawan dan budayawan. Ia lahir di Yogyakarta 18 September 1943. Pendidikan jenjang sarjana ditempuh pada program studi Sejarah di UGM (1969). Setelah tamat sarjana, ia menjadi pengajar di alamamaternya tersebut. Pada tahun 1973 -1974, ia menjalani tugas belajar di Universitas Connecticut USA dengan mendapat gelar Masternya (MA). Sementara itu, gelar pendidikan doktornya (Ph.D) di bidang sejarah ia dapatkan dari Universitas Colombia dengan judul desertasi Social Change in an Agrarian Society: Madura 1850-1940. Putri Wulansari dan Nurul Khotimah, "Membumikan Ilmu Sosial Profetik: Reaktualisasi Gagasan Profetik Kuntowijoyo dalam Tradisi Keilmuwan di Indonesia," Jurnal Pendidikan Agama Islam Universitas Wahid Hasyim, Progress, Vol.7, No. 2 (2019) :224.

${ }^{23}$ Perdana Boy ZTF, "Prophetic Social Sciences: Toward an Islamic-Based Transformative Social Sciences,"Indonesian Journal of Islam and Muslim Societies, Vol.1, Number.1(2011):95-96. Lahirnya paradigma profeti atau Ilmu Sosial Profetik terinspirasi dari dua tokoh besar (Muhammad Iqbal dan Roger Garaudy, seorang filosof dari Prancis). Athoillah Islamy, Nurul Istiani, "Aktualisasi Nilai-nilai Profetik dalam Pendidikan Keluarga di Tengah Pandemi Covid-19," Mawa'izh : Jurnal Dakwah dan Pengembangan Sosial Kemanusiaan, Vol. 11, No.2 (2020): 36.

${ }^{24}$ Husnul Muttaqin, "Menuju Sosiologi Profetik," Sosiologi Reflektif, Vol. 10, No. 1

(2015) : 221-222. 
integral saling berkaitan dalam membumikan nilai-nilai Islam dalam kehidupan sosial. ${ }^{25}$ Penjelasan lebih lanjut tentang tiga nilai dasar dalam paradigma ilmu sosial profetik, sebagai berikut.

\section{Humanisasi.}

Humanisasi merupakan nilai profetik yang lahir pemaknaan terhadap ajaran Islam yang berupa amar ma'ruf (menegakkan kebenaran). ${ }^{26}$ Jika merujuk pada pendapat Abdul Karim Syeikh, term ma"ruf sejatinya memiliki makna yang beragam. Meski biasa dimaknai dengan kebaikan, akan tetapi sejatinya memuat makna keutamaan, kebenaran, keadilan, kelayakan, pantas, patut dan bakti. ${ }^{27}$ Dengan demikian dapat dipahami bahwa pengejawantahan konsep amar ma'ruf sebagai landasan profetik konsep humanisasi dapat memiliki ragam bentuk, tidak hanya terbatas pada nilai kebaikan.

Dalam Ilmu Sosial Profetik (ISP), pengejawantahan nilai humanisasi bertujuan untuk memanusiakan manusia, menghilangkan kebendaan, ketergantungan, kekerasan dan kebencian dari manusia. ${ }^{28}$ Oleh sebab itu, sejatinya humanisasi memiliki titik temu dengan semangat liberalisme Barat. Namun terdapat perbedaan fundamental, jika peradaban Barat berpijak pada humanisme antroposentris. Pandangan antroposentris ini memandang bahwa eksistensi kehidupan tidak berpusat pada Tuhan, melainkan dibangun oleh manusia sendiri. ${ }^{29}$ Sedangkan ide humanisme

${ }^{25}$ Maskur, "Ilmu Sosial Profetik Kuntowijoyo (Telaah atas Relasi Humanisasi, Liberasi, dan Transendensi)," (Tesis Pascasarjana Universitas Islam Negeri Alauddin Makassar, 2012), 127.

${ }^{26}$ Husnul Muttaqin, "Menuju Sosiologi Profetik," 225.

27 Abdul Karim Syeikh, "Rekonstruksi Makna Dan Metode Penerapan Amar Ma'ruf Nahi Munkar Berdasarkan Al-Qur'an," Al-Idarah: Jurnal Manajemen dan Administrasi Islam, Vol.2, No.2 (2018) :19.

${ }^{28}$ Muhammad Zainal Abidin, Paradigma Islam dalam Membangun Paradigma Ilmu Integralistik: Membaca Kuntowijoyo (Banjarmasin :IAIN Antasari Press, 2016), 155

${ }^{29}$ Husnul Muttaqin, "Menuju Sosiologi Profetik,"225-226. 
yang digagas Kuntowijoyo berpijak pada nilai humanisme teosentris. Oleh karena itu, ide humanisasi Kuntowijoyo tidak dapat dilepas dari dimensi transendensi yang menjadi dasar filosofisnya. ${ }^{30}$ Melalui humanisme teosentris yang digagasnya, Kuntowijoyo ingin mengangkat kembali martabat manusia, yakni menekankan kesadaran manusia kembali untuk memusatkan dirinya kepada Tuhan, dengan tetap menekankan orientasi untuk kemaslahatan hidup manusia manusia itu sendiri. Dengan demikian, peradaban manusia tidak lagi diukur dengan semangat rasionalitas semata, melainkan penting menekankan semangat transendensi yang bersumber dari ajaran agama (Islam). ${ }^{31}$ Pandangan demikian, meniscayakan bahwa terdapat dua macam sumber pengetahuan dan kebenaran yang ingin ditekankan Kuntowijoyo, yakni bersumber dari Tuhan dan dari manusia. ${ }^{32}$ Dari sini dapat dipahami bahwa humanisasi dalam paradigma ilmu sosial profetik yang digagas oleh Kuntowijoyo sejatinya lebih tepat disebut humanisasi teoantroposentris, karena melandaskan pada nilai-nilai ketuhanan yang bersumber dari ajaran Islam, dan nilai-nilai kemanusiaan yang bersumber dari akal sehat manusia.

${ }^{30}$ Lahirnyan ide humanisme teosentris Kuntowijoyo tidak dapat dilepaskan dari fenomena terjadinya industrialisasi di Indonesia. Di mana keberadaan industrialisasi telah memberikan pengaruh dan dampak besar terhadap kebudayaan masyarakat yang berupa yakni perubahan sosial yang tidak sedikit menimbulkan ragam bentuk dehumanisasi. Di samping itu, fenomena krisis kepekaan manusia terhadap problem sosial seakan-akan mencerminkan bahwasanya yang terjadi di dalam masyarakat merupakan hal yang natural, sehingga ia menegaskan perlu adanya kesadaran keimanan untuk kembali mengangkat martabat manusia agar manusia tidak lagi diukur dari segi rasionalitasnya saja, melainkan dari transendensinya. Isfaroh, Humanisme Teosentris : Telaah Sosiologi Pengetahuan Pemikiran Kuntowijoyo," Panangkaran, Jurnal Penelitian Agama dan Masyarakat, Vol.3, No.2 (2019) :211

${ }^{31}$ Husnul Muttaqin, "Menuju Sosiologi Profetik," $226 .$.

${ }^{32}$ Muhammad Zainal Abidin, Paradigma Islam dalam Membangun Paradigma Ilmu Integralistik: Membaca Kuntowijoyo, 145. 


\section{Liberasi}

Jika humanisasi melandaskan pada refleksi pemaknaan ajaran amar makruf, maka liberasi merupakan pemaknaan kreatif dari ajaran Islam yang berupa nahi munkar (mencegah kemunkaran). ${ }^{33}$ Menurut Abdul Karim Syeikh, istilah munkar tidak hanya ditujukan pada perkara yang dingkari dan dilarang oleh ajaran agama, melainkan juga tidak dapat diterima oleh akal sehat dan budaya dan adat dalam suatu masyarakat. ${ }^{34}$ Dengan demikian dapat dipahami bahwa indikator perkara yang masuk dalam kategori munkar tidak hanya didasarkan pada landasan teologis normatf semata, melainkan norma sosiologis maupun antropologis dalam kehidupan manusia.

Tidak dapat dipungkiri bahwa ide liberasi dalam Ilmu Sosial Profetik dapat diparalelkan dengan pelbagai ide sosialisme Barat, seperti marxisme, ${ }^{35}$ komunisme, ${ }^{36}$ teologi pembebasan, ${ }^{37}$ dan lain sebagainya.

${ }^{33}$ Husnul Muttaqin, "Menuju Sosiologi Profetik 226

${ }^{34}$ Abdul Karim Syeikh, "Rekonstruksi Makna Dan Metode Penerapan Amar Ma'ruf Nahi Munkar Berdasarkan Al-Qur'an,"19.

${ }^{35}$ Lahirnya marxisme dilatarbelakangi oleh bentuk protes Marx terhadap paham kapitalisme. Karl Marx memandang kaum kapitalis telah mengumpulkan uang dengan mengorbankan kehidupan kaum proletar. Marx menyatakan bahwa masalah kapitalisme timbul karena adanya "kepemilikan pribadi" dan dominasi kekayaan oleh orang-orang kaya. Menurut Mark, untuk mensejahterakan kaum proletar, maka paham kapitalisme harus diganti dengan paham komunisme. Marx menambahkan jika kapitalisme tetap dibiarkan, maka kaum proletar dapat melakukan pemberontakan dan menuntut keadilan. Pandangan demikianlah yang menjadi ide dasar dari marxisme. Eko Bahtiyar, "Kritik Islam Terhadap Konsep Marxisme Tentang Pengentasan Kemiskinan," Profetika : Jurnal Studi Islam, Vol. 16, No. 2 (2015):130.

36 Term komunisme dalam ilmu sosial dipahami sebagai antologi pelbagai doktrin Marxis yang berupa kritik terhadap kapitalisme dan teori liberal dengan melakukan revolusi kaum proletar menjadi masyarakat komunis. Keberadaan Masyarakat komunis yang dimaksud, yakni kehidupan masyarakat yang bebas dari kemiskinan, tanpa kelas sosial, kesenjangan pembagian kerja, otoritas lembaga yang menjadi alat paksaan dan superioritas antar kelas sosial. Fadhilah Rachmawati," Jurnal Sosiologi Agama Indonesia, Vol. 1, No. 1 (2020):68.

${ }^{37}$ Mengelaborasi mengenai konstruksi pemikiran teologi pembebasan dari berbagai mazhab pemikiran baik itu pe mikiran

teologi pembebasan di dunia Barat, Islam, maupun Latin. Adapun ketiga mazhab tersebut memang memiliki konstruksi politik terhadap pembebasan yang sama yakni melawan ketimpangan yang diakibatkan oleh pengaruh rezim otoriter. Namun yang 
Namun dalam paradigma Ilmu Sosial Profetik, ide liberasi dimaksudkan dalam konteks ilmu yang dilandaskan pada pelbagai nilai transendental ajaran agama. Oleh sebab itu, nilai liberatif dalam Ilmu Sosial Profetik diposisikan dalam konteks ilmu sosial yang memiliki tanggung jawab profetik untuk membebaskan kehidupan manusia dari berbagai tindakan yang bertentangan dengan semangat kemanusiaan itu sendiri, seperti kekejaman, kemiskinan, pemerasan, dominasi struktur yang menindas, diksriminasi, hegemoni, tirani, dan lain sebagainya. ${ }^{38}$

Terdapat empat objek utama yang menjadi target sasaran ide liberasi Kuntowijoyo. Pertama, liberasi sistem pengetahuan. Liberasi dalam bidang ini berupaya untuk membebaskan manusia orang dari sistem pengetahuan yang materialistis, dan dari dominasi struktur kelas, dan seks. Kedua, liberasi dalam sistem sosial. Liberasi dalam bidang ini bertujuan untuk menjaga manusia dari dampak negartif sistem sosial industrial. Ketiga, liberasi dari belenggu sistem ekonomi yang berdampak negatif pada kesenjangan kesejahteraan umat manusia. Keempat, liberasi dalam sistem politik yang bertujuan untuk membebaskan sistem dari otoriter, diktator, dan neofeodalisme. ${ }^{39}$

\section{Transendensi}

Transendensi merupakan landasan fundamental dari dua unsur sebelumnya (humanisasi dan liberasi). Nilai transendensi berpijak dari

menjadi menarik adalah masing- masing entitas teologi pembebasan sendiri berkembang sesuai dengan karakteristik berbeda. Teologi pembebasan yang berkembang di Barat sendiri lebih b anyak didominasi akar Protestanisme, namun lebih banyak berkembang dalam ranah pemikiran. Teologi pembebasan dalam Islam didominasi pemikiran untuk melawan ketimpangan dan kebodohan. Teologi pembebasan dalam Latin lebih banyak didominasi pemikiran Gereja Romawi dan mengarah pad a praksis gerakan. Wasisto Raharjo Jati, "Agama dan Politik: Teologi Pembebasan sebagai Arena Profetisasi Agama," Walisongo, Vol.22, No.1 (2014):135-136.

${ }^{38}$ Husnul Muttaqin, "Menuju Sosiologi Profetik 226.

${ }^{39}$ Muhammad Zainal Abidin, Paradigma Islam dalam Membangun Paradigma Ilmu Integralistik : Membaca Kuntowijoyo, 157. 
ajaran Islam yang berupa perintah untuk menjaga komitmen keimanan. Pada nilai transendensi ini, pelbagai nilai dasar keimanan dalam ajaran Islam dijadikan sebagai bagian inti dan penting dalam membangun sebuah peradaban umat manusia. Oleh sebab itu, transendensi menempatkan nilai-nilai ajaran Islam pada posisi yang sangat sentral dalam paradigma Ilmu Sosial Profetik. ${ }^{40}$ Dengan kata lain, transendensi dapat dipahami sebagai kesadaran orientasi kerja manusia yang paralel dengan pernyataan Tuhan tentang visi penciptaan manusia yakni untuk beribadah. ${ }^{41}$

Dalam paradigma ilmu sosial profetik, transendensi berperan penting dalam membimbing dan menuntun tujuan dan makna hidup manusia. Transendensi memberikan arah dan tujuan untuk apa tindakan humanisasi dan liberasi dilakukan. ${ }^{42}$ Oleh sebab itu, humanisasi, liberasi, dan transendensi merupakan hal yang dipandang secara integral daalam paradigma Ilmu Sosial Profetik. ${ }^{43}$

Sampai di sini dapat dipahami bahwa trilogi Ilmu Sosial Profetik (ISP) yang digagas Kuntowijoyo, yakni humanisasi, liberasi dan transendensi merupakan nilai-nilai yang saling terkait dan sinergis dalam pembentukan peradaban umat manusia, bukan nilai-nilai yang dikotomikan dalam mencapai sebuah tujuan.

${ }^{40}$ Husnul Muttaqin, “Menuju Sosiologi Profetik 227-228.

${ }^{41}$ Muhammad Zainal Abidin, Paradigma Islam dalam Membangun Paradigma Ilmu Integralistik : Membaca Kuntowijoyo, 158.

${ }^{42}$ Husnul Muttaqin, "Menuju Sosiologi Profetik, 228. Dalam perpektif psikologi Islam, Islam merupakan sebuah ajaran agama yang memuat sumber nilai yang dapat dijadikan pedoman hidup dalam membentuk kondisi psikis dan perilaku manusia yang baik. Oleh karenanya, seorang yang memahami ajaran Islam dengan benar serta menjalankan segala aturan agama tersebut, akan tercermin melalui kemuliaan perilakunya sehari-hari. Athoillah Islamy, "Dialectic Motivation, Behavior And Spiritual Peak Experience In The Perspective Of Islamic Psychology," Alfuad : Jurnal Sosial Keagamaan, Vol.3, No.2 (2019):38.

${ }^{43}$ Maskur, "Ilmu Sosial Profetik Kuntowijoyo (Telaah atas Relasi Humanisasi, Liberasi, dan Transendensi)," (Tesis Pascasarjana Universitas Islam Negeri Alauddin Makassar, 2012), 127. 


\section{E. NILAI-NILAI SOSIAL PROFETIK DALAM PRINSIP KODE ETIK POLITIK DI INDONESIA}

Pada sub bab pembahasan ini akan diuraikan analisa eksploratif nilainilai sosial profetik yang termuat dalam pelbagai prinsip kode etik politisi dan partai politik di Indonesia. Dalam naskah kode etik politisi dan partai politik yang diterbitkan oleh Direktorat Pendidikan dan Pelayanan Masyarakat Kedeputian Pencegahan, Komisi Pemberantasan Korupsi Bekerja sama dengan Pusat Penelitian Politik, LIPI, disebutkan bahwa terdapat pelbagai prinsip kode etik yang harus dijaga oleh politisi dan partai politik, antara lain, sebagai berikut.

\section{Prinsip Kepentingan Umum}

Keberadaan partai politik sebagai institusi publik dituntut harus dapat berorientasi pada kepentingan umum dalam kehidupan masyarakat. Oleh karena itu, setiap kebijakan maupun aktifitas partai politik harus berorientasi pada kemaslahatan publik. Dengan demikian, para politisi yang duduk di lembaga pemerintah harus senantiasa memperjuangkan kepentingan umum sebagai mandatnya. Oleh sebab itu, kepentingan yang diusung dalam berpolitik haruslah mengarah pada kepentingan yang dimaksudkan demi terwujudnya kepentingan nasional bukan individual maupun kelompok. ${ }^{44}$

Prinsip kemaslahatan publik di atas sejatinya paralel dengan nilai sosial profetik dalam ajaran Islam yang menekankan pentingnya menjalin dan persaudaraan kemanusiaan (ukhuwah insaniyah) yang dimanifestasikan dalam bentuk solidaritas kemanusiaan (ta'awun insani) dalam kehidupan sosial. Hamka Haq sebagaimana yang dikutip Maemunah mengatakan bahwa selain lima aspek yang menjadi tujuan

\footnotetext{
${ }^{44}$ Syamsuddin Haris dkk, Naskah Kode Etik Politisi dan Partai Politik, 32.
} 
hukum Islam (maqasid al-shariah al-khomsah) ${ }^{45}$ dalam konteks kehidupan bernegara dan berbangsa diperlukan kesadaran akan hifz ummah (menjaga kemaslahatan umat). ${ }^{46}$

Dengan demikian dapat dikatakan bahwa prinsip kepentingan publik merupakan prinsip yang sejalan dengan semangat ajaran Islam tentang pentingnya menjaga kemaslahatan hidup umat manusia.

\section{Prinsip Kejujuran dan Transparansi}

Kejujuran merupakan prinsip yang harus melekat dalam perilaku dan tindakan politik. Prinsip kejujuran ini mengarahkan para politisi untuk bersikap fair, dan tidak berbohong, bebas dari penipuan dan pelbagai bentuk ketidakjujuran lainnya. Sebagai contoh perbuatan korupsi merupakan perilaku tidak jujur yang melanggar kepercayaan rakyat. ${ }^{47}$ Dalam prinsip kejujuran ini menekankan konsistensi antara ucapan dan sikap seorang politisi. Begitu juga dengan keberadaan partai politik yang menjadi bagian integral dari demokrasi harus menjunjung tinggi nilai kejujuran dalam menjalankan tugas politik di masyarakat. ${ }^{48}$

Sebagaimana prinsip kejujuran, prinsip transparansi juga menekankan pemeliharaan akses atas informasi dan berkaitan erat dengan akuntabilitas dan kualitas politisi maupun partai politik yang

${ }^{45}$ Al-Ghazali sebagaimana yang dikutip Ahamd Sarwat menjelaskan terdapat lima tujuan hukum Islam (maqashid al-syariah al-khomsah), yakni proteksi agama (hifz din), proteksi jiwa (hifz nafs), proteksi akal (hifz aql), proteksi keturunan (hifz nasl), dan proteksi harta (hifz mal). Ahmad Sarwat, Maqashid Syariah (Jakarta : Rumah Fiqh Publishing, 2019), 18.

${ }^{46}$ Maimunah, "Politik Islam Persfektif Maqashid Syariah," El-Maslahah Journal, Vol.8, No.1 (2018): 20-21.

${ }^{47}$ Tidak dapat dibantah bahwa tidak banyak dijumpai guru politik yang baik, yang mengajarkan bagaimana sikap berpolitik agar tidak sekedar merebutkan kekuasaan, melainkan penting penekanan atas penghayatan etika serta moral. Politik yang mengedepankan take and give, berkonsensus, dan pengorbanan, kurangnya komunikasi politik juga menjadi faktor penyebab lahirnya politisi yang tidak jujur. Prihatin Dwihantoro, "Etika Dan Kejujuran Dalam Berpolitik," Politika, Vol. 4, No. 2 (2013): 19 .

${ }^{48}$ Syamsuddin Haris dkk, Naskah Kode Etik Politisi dan Partai Politik, 32-33. 
baik. Setiap politisi dan partai politik harus dapat membuka akses bagi publik untuk segala bentuk informasi terkait dengan parpol dan dirinya secara akurat, benar kepada publik. Prinsip dasar transparansi ini mempertimbangkan bagaimana informasi dapat dengan jelas kepada publik terkait kebijakan politik yang dilakukan oleh politisi maupun partai politk. 49

Prinsip kejujuran dan transpransi sebagaimana di atas sejalan dengan nilai sosial profetik dalam ajaran Islam. Sebagaimana penting diketahui bahwa al-Quran menekankan pentingya sikap kejujuran (shiddiq). Hal demikian dapat dilihat dari penyebutan kata jujur (shiddîq) dalam alQuran dengan frekuensi jumlah yang relatif tinggi sampai 154 kali dengan 49 bentuk derivasi kata. Tidak hanya dalam al-Qur'an dalam pelbagai hadis Nabi Muhammad Saw juga banyak sekali anjuran bersikap jujur. ${ }^{50}$ Di samping itu, jujur juga merupakan salah satu sifat wajib yang dimiliki Nabi. ${ }^{51}$ Dari sini dapat disimpulkan bahwa prinsip kejujuran dalam kode etik politik merupakan prinsip yang paralel dengan semangat ajaran sosial profetik dalam Islam berupa manifestasi sifat shiddiq.

\section{Prinsip Integritas dan Profesional}

Prinsip integritas menekankan tindakan politik harus sesuai dengan pelbagai nilai, keyakinan, atau prinsip yang telah disepakati bersama. Oleh karenanya, prinsip integritas menjadi elemen karakter atas pengakuan profesionalisme para politisi maupun partai politik dalam kepercayaan publik. Dengan memiliki integritas yang baik, politisi

\footnotetext{
${ }^{49}$ Syamsuddin Haris dkk, Naskah Kode Etik Politisi dan Partai Politik, 33.

${ }^{50}$ Raihanah, "Konsep Jujur dalam al-Qur'an," Al-Adzka, Jurnal Ilmiah Pendidikan Guru Madrasah Ibtidaiyah, Vol. VII, No. 01(2017) :21-23.

${ }^{51}$ Sakdiah, "Karakteristik Kepemimpinan Dalam Islam (Kajian Historis Filosofis ) Sifat-Sifat Rasulullah," Jurnal Al-Bayan, Vol. 22 No. 33 (2016) :38.
} 
maupun partai politik akan mendapatkan kepercayaan publik dengan mudah. ${ }^{52}$

Sementara itu, prinsip profesionalisme menekankan pentingnya tindakan politik harus sesuai dengan komitmen dan tanggungjawabnya. Dalam hal ini, politisi maupun parpol harus memprioritaskan tugas dan fungsinya di atas pelbagai kegiatan lain secara profesional. Status yang dimiliki politisi sebagai pejabat publik tidak digunakan mencari keuntungan pribadi, keluarga, kelompok dan golongan tertentu..$^{53}$

Prinsip integritas dan profesionalisme dalam berpolitik merupakan prinsip yang sejalan dengan prinsip etos kerja dalam perspektif Islam yang berupa pelbagai nilai etis yang terkandung dalam al-Qur'an dan alSunnah untuk dapat bekerja sebaik-baiknya dalam mencapai hasil yang terbaik, dengan tidak mengabaikan landasan etis atau prinsip-prinsip dasar dan umum yang sudah ditentukan dalam ajaran Islam. Di antara etos integritas dan profesionalisme kerja yang sejalan dengan ajaran Islam, yakni khaira ummah, keadilan, musyawarah, ulul albab, etos imamah, etos tauhid yang membebaskan. ${ }^{54}$ Dengan demikian integritas sebagai karakter profesionalisme kerja yang sesuai dengan prinsip atau kode etik yang telah dibangun dan disepakati bersama dalam kehidupan politik merupakan prinsip idealitas yang sejalan dengan ajaran Islam.

\section{Prinsip Akuntabilitas}

Dalam rangkan menjaga stabilitas kinerja politik, maka setiap politisi dan partai politik harus memiliki seperangkat sistem yang dibentuk berdasarkan legitimasi demokratis untuk mengendalikan, memantau, mengevaluasi dan menyesuaikan kepatutan dan efektivitas tindakan

\footnotetext{
${ }^{52}$ Syamsuddin Haris dkk, Naskah Kode Etik Politisi dan Partai Politik, 33.

${ }^{53}$ Syamsuddin Haris dkk, Naskah Kode Etik Politisi dan Partai Politik, 34.

${ }^{54}$ Mohammad Irham, " Etos Kerja Dalam Perspektif Islam," Jurnal Substantia,
} Vol. 14, No. 1 (2012) : 21-22. 
politik kepada publik. Oleh sebab itu, prinsip akuntabilitas merupakan suatu prinsip yang harus dipegang oleh politisi dan partai politik agar dapat mempertantanggunjawabkan kinerja politiknya, baik secara individual dan institusional. 55

Prinsip akuntabilitas dalam kehidupan politik merupakan prinsip atau karakter yang juga dimiliki oleh Nabi Muhammad SAW yakni sifat dapat dipercaya (amanah) atau bertanggung jawab. Sifat amanah yang dimiliki Nabi sebagai pemimpin yang bertanggungjawab dengan tugas dan kepercayaan yang diberikan oleh Allah swt. Sifat amanah ini melekat pada kepribadian Nabi dalam segala aspek kehidupan, baik agama maupun politik. ${ }^{56}$

\section{Prinsip Keadilan}

Prinsip keadilan ini merupakan prinsip meletakkan segala sesuatu pada tempatnya dan memberikan kepada individu atau kelompok yang berhak menerimanya. Tuntutan yang paling fundamental dari prinsip keadilan dalam dunia politik, yakni memberikan peluang yang sama terhadap setiap orang. Oleh sebab itu, politisi maupun parpol harus dapat berlaku adil dalam menjalankan fungsi dan peranannya bagi kemaslahatan publik, yakni tidak melakukan diskriminasi atas perbedaan suku, agama, ras, golongan status sosial ekonomi dan lain sebagainya. 57

Dalam ajaran Islam, keadilan merupakan ajaran universal yang tidak mengalami perubahan. Term keadilan sendiri disebutkan dalam alQur'an dengan beragam bentuk, antara lain al-Adl, al-Qisth dan alMizan. Menurut Fuad Abd al-Baqi sebagaimana yang dikutip oleh

\footnotetext{
${ }^{55}$ Syamsuddin Haris dkk, Naskah Kode Etik Politisi dan Partai Politik, 33-35.

${ }^{56}$ Sakdiah, "Karakteristik Kepemimpinan Dalam Islam (Kajian Historis Filosofis ) Sifat-Sifat Rasulullah," 40-41

${ }^{57}$ Syamsuddin Haris dkk, Naskah Kode Etik Politisi dan Partai Politik, 35.
} 
Zulkifli, penyebutan al-Qur'an terhadap "keadilan" dengan kata al-Adl dapat ditemukan sebanyak 28 kali. Sementara dengan kata al-Qisth sejumlah 27 kali. Kemudian dengan kata al-Mizan disebut sampai 23 kali. Hal demikian menunjkan bahwa dalam keadilan merupakan nilai sosial profetik dalam ajaran Islam yang diperintahkan kepada umat manusia untuk dimanifestasikan dalam kehidupan sosial di masyarakat. ${ }^{58}$ Sampai di sini dapat dipahami bahwa prinsip keadilan sebagai bagian dari prinsip kode etik politik di Indonesia merupakan prinsip yang senafas dengan ajaran universal Islam yang berupa perintah untuk menegakkan keadilan (al-adalah) di muka bumi.

\section{F. KESIMPULAN}

Berdasarkan uraian pembahasan penelitian ini dapat disimpulkan bahwa pelbagai prinsip kode etik politik di Indonesia yang termaktub dalam naskah kode etik politisi dan partai politik memiliki relevansi (titik temu) dengan pelbagai nilai sosial profetik dalam ajaran Islam. Hal demikian dapat dilihat dari spirit tiga pilar paradigam sosial profetik (humanisasi, liberasi, dan transendensi) yang dapat ditemukan dalam pelbagai prinsip kode etik politik sebagai berikut. Pertama, prinsip kemaslahatan publik. Prinsip ini paralel dengan ajaran Islam yang berupa menjaga persaudaraan kemanusiaan (ukhuwah insaniyah) dan solidaritas kemanusiaan (ta'awun insani). Kedua, prinsip kejujuran. Prinsip ini sejalan dengan semangat ajaran sosial profetik dalam Islam yang berupa manifestasi sifat shiddiq. Ketiga, prinsip integritas dan profesionalisme sejalan dengan ajaran Islam, yakni khaira ummah, keadilan, musyawarah, ulul albab, imamah, tauhid yang membebaskan. Keempat, prinsip akuntabilitas. Prinsip ini paralel dengan karakter yang

58 Zulkifli, “Tuntutan Keadilan dalam Perspektif Hukum Islam," Jurnal Ilmiah Syari'ah, Vol. 17, No.1(2018) : 138. 
dimiliki Nabi Muhammad SAW, yakni sifat dapat dipercaya (amanah) atau bertanggung jawab dalam segala aspek kehidupan, baik agama maupun politik. Kelima, prinsip keadilan. Prinsip ini merupakan prinsip yang senafas dengan ajaran universal Islam yang berupa perintah untuk menegakkan keadilan (al-adalah) di muka bumi.

Dengan ditemukannya nilai-nilai sosial profetik pada pelbagai prinsip kode etik politik yang termatub dalam naskah kode etik politisi dan partai politik di Indonesia, maka dapat menunjukan bahwa paradigma yang dibangun dalam kode etik politisi dan partai politik tersebut sejalan nilai-nilai sosial dalam ajaran Islam. 


\section{DAFTAR PUSTAKA}

Atamimi, Abdul Basit. Athoillah Islamy 2019, "Political Thinking And Attitude Of Religion:Study Of Political Resistance Of Kiai Ahmad Rifa'I Kalisalak Al-Jawi On Colonialism Of The Netherlands," Akademika: Jurnal Keagamaan dan Pendidikan, Vol. 15 No. 2.

Bauw, Azies. 2013. "Peranan Partai Politik Dalam Membangun Proses Demokrasi Di Indonesia(Kajian Undang-Undang Nomor 2 Tahun 2011 Tentang Partai Politik)," Legal Pluralism : Vol3, No.1.

Boy, Perdana ZTF. 2011. "Prophetic Social Sciences: Toward an Islamic-Based Transformative Social Sciences," Indonesian Journal of Islam and Muslim Societies, Vol.1, Number.1.

Budiardjo, Mariam. 2007. Dasar Ilmu Politik, Jakarta : Gramedia Pustaka Utama.

Djamil, M. Nasir, TB. Massa Djafar. 2016 “Etika Publik Pejabat Negara dalam Penyelenggaraan Pemerintahan yang Bersih," Jurnal Politik, Vol.12, No.1.

Eko Bahtiyar. 2015. “Kritik Islam Terhadap Konsep Marxisme Tentang Pengentasan Kemiskinan," Profetika : Jurnal Studi Islam, Vol. 16, No. 2.

Fadhilah Rachmawati. 2020. "Jurnal Sosiologi Agama Indonesia, Vol. 1, No. 1.

Fariz, Donal. 2019. “Pemerintahan Joko Widodo dan Serangan Politik Terhadap KPK," Jurnal Antikorupsi Integritas, Vol. 5 No.2.

Ganjar, Ari Herdiansah. 2017. "Pragmatisme Partai Islam Di Indonesia: Pendekatan Tindakan Sosial," Sosioglobal : Jurnal Pemikiran Politik, Vol.1, No.2.

Habibi, Nur. 2014. "Praktik Pengawasan Etika Dewan Perwakilan Rakyat Republik Indonesia," Jurnal Cita Hukum, Vol.1, No.1 (2014).

Haris, Syamsuddin. 2016. dkk, Naskah Kode Etik Politisi dan Partai Politik, Jakarta : P2Politik LIPI.

Harto, Kasinyo. 2014. “Pendidikan Anti Korupsi Berbasis Agama," Intizar, 
Vol. 20, No. 1.

Ida Bagus Ketut Weda, 2013. “Korupsi Dalam Patologi Sosial : Sebab, Akibat Dan Penanganannya Untuk Pembangunan Di Indonesia," Jurnal Advokasi, Vol.3, No.2.

Isfaroh. 2019. Humanisme Teosentris : Telaah Sosiologi Pengetahuan Pemikiran Kuntowijoyo," Panangkaran, Jurnal Penelitian Agama dan Masyarakat, Vol.3, No.2.

Ishaq, 2017. Metode Penelitian Hukum dan Penulisan Skripsi, Tesis serta Disertasi, Bandung : Alfabeta.

Islamy, Athoillah. 2019. “Eksistensi Hukum Keluarga Islam di Indonesia dalam Kontestasi Politik Hukum dan Liberalisme Pemikiran Islam," AlIstinbath: Jurnal Hukum Islam, Vol.4, No.2

Islamy, Athoillah. 2019. “Dialectic Motivation, Behavior And Spiritual Peak Experience In The Perspective Of Islamic Psychology," Alfuad : Jurnal Sosial Keagamaan, Vol.3, No.2.

Ismansyah, Purwantoro Agung Sulistyo. 2010. "Permasalahan Korupsi, Kolusi, dan Nepotisme di Daerah serta Strategi Penanggulangannya," Demokrasi, Vol. IX No. 1.

Islamy, Athoillah, Nurul Istiani. 2020 “Aktualisasi Nilai-nilai Profetik dalam Pendidikan Keluarga di Tengah Pandemi Covid-19," Mawa'izh : Jurnal Dakwah dan Pengembangan Sosial Kemanusiaan, Vol. 11, No.2.

Istiani, Nurul, Athoillah Islamy. 2018.“Objektifikasi Nilai-nilai Psiko Sufistik dalam Pendidikan Spritual," Hikmatuna : Journal Integrative For Islamic Studies, Vol. 4, No. 2.

Kusumawati, Mustika Purbaningrum. 2019. “Harmonisasi Antara Etika Publik Dan Kebijakan Publik," Jurnal Yuridis, Vol. 6 No. 1

Latipah. 2017 "Korupsi di Parlemen," 'Adalah : Buletin Hukum dan Keadilan, Vol.1,No.1.

Maimunah. 2018. "Politik Islam Persfektif Maqashid Syariah," El-Maslahah 
Journal, Vol.8, No.1.

Mariana, Dede, Luthfi Hamzah Husin. 2017. “Democracy, Local Election, And Political Dynasty In Indonesian Politics," Jurnal Wacana Politik, Vo.2, No.2.

Maskur. 2012. "Ilmu Sosial Profetik Kuntowijoyo (Telaah atas Relasi Humanisasi, Liberasi, dan Transendensi)," (Tesis Pascasarjana Universitas Islam Negeri Alauddin Makassar).

Mohammad Irham. 2012. "Etos Kerja Dalam Perspektif Islam," Jurnal Substantia, Vol. 14, No. 1.

Moleong, Lexy J. 2017. Metodologi Penelitian Kualitatif, Bandung : Remaja Rosdakarya.

Muhammad Zainal Abidin. 2016 Paradigma Islam dalam Membangun Paradigma Ilmu Integralistik : Membaca Kuntowijoyo, Banjarmasin :IAIN Antasari Press.

Muttaqin, Husnul. 2015. "Menuju Sosiologi Profetik," Sosiologi Reflektif, Vol. 10, No. 1.

Panduan Karya Tulis Ilmiah Pascasarjana UIN Walisongo, Semarang : Pascasarjana UIN Walisongo, 2018.

Prihatin Dwihantoro. 2013. “Etika Dan Kejujuran Dalam Berpolitik," Politika, Vol. 4, No. 2.

Raihanah. 2018. "Konsep Jujur dalam al-Qur'an," Al-Adzka, Jurnal Ilmiah Pendidikan Guru Madrasah Ibtidaiyah, Vol. VII, No. 01(2017) :21-23.ournal, Vol.8, No.1.

Sakdiah. 2016. “Karakteristik Kepemimpinan Dalam Islam (Kajian Historis Filosofis ) Sifat-Sifat Rasulullah," Jurnal Al-Bayan, Vol. 22 No. 33.

Sarwat, Ahmad. 209 Maqashid Syariah, Jakarta : Rumah Fiqh Publishing.

Setiawan, Anang, Erinda Alfiani Fauzi. 2019. “Etika Kepemimpinan Politik Dalam Penyelenggaraan Pemerintahan Indonesia," Jurnal Pemerintahan dan Kebijakan, Vol.1, No.1. 
Athoillah Islamy

Setiawan, Irfan. 2016. "Mengikis Perilaku Korupsi Pada Birokrasi Pemerintahan," Jurnal Ilmu Pemerintahan Widyapraja IPDN Vol XLII No. 1. Syeikh, Abdul Karim. 2018. “Rekonstruksi Makna Dan Metode Penerapan Amar Ma'ruf Nahi Munkar Berdasarkan Al-Qur'an," Al-Idarah: Jurnal Manajemen dan Administrasi Islam, Vol.2, No.2.

Taufikurrahman. 2019. "Fungsi partai politik pada kekuasaan eksekutif dan legislatif berdasar pada sistem pemerintahan di Indonesia," Jurnal Civics: Media Kajian Kewarganegaraan, Vol. 16 No. 2.

Wayan, I Yuda Satria, I Wayan Suardana, Ida Bagus Surya Darmajaya. 2013. “Kewenangan Komisi Pemberantasan Korupsi (Kpk) Dalam Upaya Pemberantasan Tindak Pidana Korupsi Di Indonesia," Ketha Semaya, Vol.1, No.1.

Wulansari, Putri dan Nurul Khotimah. 2019. “Membumikan Ilmu Sosial Profetik: Reaktualisasi Gagasan Profetik Kuntowijoyo dalam Tradisi Keilmuwan di Indonesia," Jurnal Pendidikan Agama Islam Universitas Wahid Hasyim, Progress, Vol.7, No. 2.

Yanto, Dwi. 2017. “Etika Politik Pancasila," Ittihad Jurnal Kopertais Wilayah XI Kalimantan, Vol.15, No.27.

Yunus, Nur Rohim. 2014. “Etika dan Moralitas Politik Anggota Dewan," Mizan: Jurnal Ilmu Syariah. Vol.2, No. 2.

Zulkifli. 2018. “Tuntutan Keadilan dalam Perspektif Hukum Islam," Jurnal Ilmiah Syari'ah, Vol. 17, No.1. 